\section{Original researches}

Received: 10 August 202 Revised: 20 Auguat 2021

Accepted: 07 September 2021

Mykolayiv National Agrarian University, George Gongadze Str., 9, Mykolayiv, 54020, Ukraine

Tel.: +38-050-991-53-14 E-mail: kssnai10108@gmail.com

Cite this article: Kramarenko, A. S., \& Kramarenko, S. S. (2021). Microsatellite DNA heterozygosity and weight performance in Southern meat cattle breed heifers. Theoretical and Applied Veterinary Medicine, 9(3), 107-114. doi: $10.32819 / 2021.93017$

\title{
Microsatellite DNA heterozygosity and weight performance in Southern meat cattle breed heifers
}

\author{
A. S. Kramarenko, S. S. Kramarenko \\ Mykolayiv National Agrarian University, Mykolayiv, Ukraine
}

\begin{abstract}
The purpose of this study was to determine whether heterozygosity (assessed using microsatellite genotypes) was correlated with the body weight of heifers from birth to 18 months. The study was conducted on the heifers' herd of the Taurian intra-breed type Southern meat cattle breed at Askaniiske State Research Enterprise (Ukraine, Kherson Region). During the study, we used ten microsatellite loci recommended by International Society for Animal Genetics (ISAG) TGLA227, BM2113, TGLA53, ETH10, SPS115, TGLA122, INRA023, BM1818, ETH3 and BM1824. The heifer's body weight was measured at birth, at weaning, and at the age $8,12,15$ and 18 months. Individual heterozygosity estimates (for each microsatellite loci separately) and microsatellite multilocus heterozygosity (for all used loci) estimates (MLH) were used in the analysis. ANOVA was used to determine the relationship of the dependent effects (body weight at different ages) to single locus heterozygosity using two classes: 0 (for homozygous individuals) and 1 (for heterozygous individuals). In addition, the following indicators were calculated for each genotype: the squared distances $\left(d^{2}\right)$ between the length of both alleles within the individual genotype for each microsatellite loci, as well as the mean squared distance (multilocus $d^{2}$ ) between the lengths of both alleles within the individual genotype for ten microsatellite loci. Spearman's rank correlation coefficients were used to measure the association between $d^{2}$ scores (for each microsatellite loci) and body weight at different ages. The influence of different grades of estimates of MLH and mean $d^{2}$ classes was also assessed based on ANOVA. Heterozygosity at locus $B M 2113$ was significantly $(P<0.01)$ associated with heifer's body weight at the age of 15 months and heterozygosity at locus BM1818 was significantly $(P<0.05)$ associated with heifer's body weight at the age of 8 months. Significant Spearman's rank correlations $(P<0.01 \ldots 0.05)$ were also observed between the body weight and $d^{2}$ score for four microsatellite loci BM2113, SPS115, ETH3 and BM1824. Individual mean heterozygosity estimates for 10 microsatellite loci and mean $d^{2}$ estimates were weakly associated with weight performance in Southern meat cattle breed heifers.
\end{abstract}

Keywords: microsatellite DNA; heterozygosity; weight performance; heifers; Southern meat cattle breed

\section{Гетерозиготність за мікросателітними ДНК-маркерами та жива маса телиць південної м'ясної породи}

\section{О. С. Крамаренко, С. С. Крамаренко}

Миколаївський національний аграрний університет, Миколаїв, Україна

Анотація. Мета дослідження - визначення асоціації між гетерозиготністю (оцінена на підставі генотипів за мікросателітами) та живою масою телиць від народження до 18 міс. Дослідження проведено на поголів”ї телиць таврійського внутрішньопородного типу південної м’ясної породи в умовах ДП «ДГ Асканійське» Асканійської державної сільськогосподарської дослідної станції (Україна, Херсонська обл.). Під час аналізу використано 10 локусів мікросателів ДНК (МС-ДНК), що рекомендовано Міжнародною спілкою генетики тварин (ISAG) - TGLA227, BM2113, TGLA53, ETH10, SPS115, TGLA122, INRA023, BM1818, ETH3 та BM1824). Живу масу телиць визначено при народженні, при відлученні, у віці 8, 12, 15 та 18 місяців. Оцінки індивідуальної гетерозиготності (для кожного мікросателітного локусу окремо), а також оцінки мікросателітної мультилокусної гетерозиготності (для всіх локусів одночасно) було використано в аналізі. Визначення зв'язку між залежними змінними (жива маса в різному віці) та гетерозиготністю по кожному локусу, використовуючи два класи - 0 (для гомозиготних особин) та 1 (для гетерозиготних особин), проведено на підставі алгоритму дисперсійного аналізу. Крім того, для кожного генотипу розраховано наступні показники: квадрат дистанції (міра $d^{2}$ ) між довжиною обох алелів у межах індивідуального генотипу для кожного локусу МС-ДНК, а також середній квадрат дистанції (мультилокусна $d^{2}$ ) між довжиною обох алелів у межах індивідуального генотипу для всіх 10 локусів МС-ДНК. Для оцінки асоціації між оцінками $d^{2}$ (для кожного локусу МС-ДНК) та живою масою в різному віці використано коефіцієнти рангової кореляції Спірмена. Вплив різних градацій оцінок мультилокусної гетерозиготності та середньої мультилокусної $d^{2}$ також оцінено на підставі алгоритму дисперсійного аналізу. Гетерозиготність за локусом $B M 2113$ була вірогідно $(P<0,01)$ пов'язана із живою масою телиць у віці 15 міс., а гетерозиготність за локусом $B M 1818$ була вірогідно $(P<0,05)$ пов'язана із живою масою телиць у віці 8 міс. Вірогідні оцінки коефіцієнту рангової кореляції Спірмена $(P<0,01 \ldots 0,05)$ також спостерігалися між живою масою та мірою $d^{2}$ для чотирьох мікросателітних локусів - BM2113, $S P S 115, E T H 3$ та BM1824. Оцінки індивідуальної гетерозиготності для 10 локусів МС-ДНК та середні мультилокусні оцінки $d^{2}$ слабко пов'язані із живою масою телиць південної м'ясної породи.

Ключові слова: мікросателіти ДНК; гетерозиготність; жива маса; телиці; південна м’ясна порода. 


\section{Вступ}

Не зважаючи на те, що a priori мікросателіти ДНК (МСДНК) це нейтральні молекулярно-генетичні маркери, починаючи з середини 1990-х років почали з'являтися докази наявності вірогідних асоціацій між присутністю певних алелів локусів МС-ДНК у генотипі з ознаками продуктивності сільськогосподарських тварин (Kramarenko et al., 2020). Паралельно $з$ цим встановлено, що позитивний уплив на розвиток ознак, пов'язаних із загальною пристосованістю особин у популяціях диких тварин, має також рівень гетерозиготності як за окремими структурними генами і локусами МС-ДНК, так й індивідуальні оцінки мультилокусної гетерозиготності. Прояв такого зв'язку набув визначення «кореляція між гетерозиготністю та пристосованістю» (heterozygosity-fitness correlation, HFC) і першою роботою, де продемонстровано цей феномен $\epsilon$ піонерське дослідження Singh \& Zouros (1978) на устриці. Дві основні гіпотези висунуто для пояснення цього феномену й обидві вони розглядають важливість таких типів міжалельної взаємодії, як домінування та наддомінування (гетерозис), а також нерівноважне зчеплення між алелями різних генів (Zouros, 1993). При цьому, оскільки доведено, що кореляція має місце не лише із гетерозиготністю структурних генів, але й нейтральних МСДНК, більш обгрунтованою вважається гіпотеза «асоиіативного наддомінування» (associative overdominance) (Jiang et al., 2005; Han et al., 2013).

Хоча негативні наслідки інбридингу та зниження гетерозиготності на відтворювальні якості та виживаність у популяціях диких тварин вже добре вивчено, відомо небагато досліджень щодо їх впливу на ознаки продуктивності у свійських і сільськогосподарських тварин. Протягом останніх 20 років з'явилася низка публікацій, що розглядають вплив різних оцінок гетерозиготності (коефіцієнт інбридингу, гетерозиготність та міра $d^{2}$ як для окремих структурних генів і локусів МС-ДНК, так й їх мультилокусна оцінка) на ознаки тварин, що розводяться в штучних умовах - риб (Appleyard et al., 2001), хутрових звірів (Kashtanov et al., 2003), курей (Liu et al., 2006), качок (Agatep, 2015), свиней (Wu et al., 2001; Liu et al., 2003; Jiang et al., 2005; Zhang et al., 2005; Iversen et al., 2019), кіз (Han et al., 2013), коней (Curik et al., 2003; Luís et al., 2007), домашніх овець (Smith et a., 2012; Valilou et al., 2016), яків (Jiang et al., 2004) та свійської худоби (Driscoll et al., 2011).

При цьому, залишається майже невивченим питання можливого зв'язку між гетерозиготністю (як у якісній, так і кількісній формі) та динамікою живої маси худоби м'ясних порід. Опубліковані раніше результати стосувалися, насамперед, росту, розвитку та м'ясних якостей свиней (Iversen et al., 2019).

Таким чином, основна мета роботи - вивчення зв'язку між гетерозиготністю (як на рівні окремих локусів, так й індивідуальною оцінкою мультилокусної гетерозиготності) за 10 локусами МС-ДНК та живою масою телиць південної м'ясної породи у різному віці.

\section{Матеріал і методи досліджень}

Дослідження проведено на поголів'ї телиць таврійського внутрішньопородного типу південної м'ясної породи (ПМП) (загалом - 192 голови) ДП «ДГ Асканійське» Асканійської державної сільськогосподарської дослідної станції Інституту зрошуваного землеробства НААН Каховського району Херсонської області. Частина 3 них представляла низькокровний за зебу підтип (НК), а інша частина - висококровний за зебу підтип (ВК) (Kramarenko, 2017).

У дослідженнях використано 10 мікросателітних локусів, що рекомендовані Міжнародною спілкою генетики тварин (ISAG) - TGLA227, BM2113, TGLA53, ETH10, SPS115, TGLA122, INRA023, BM1818, ETH3 та BM1824. Усі лабораторні дослідження проведено в умовах Лабораторії молекулярних основ селекції тварин Центру біотехнології та молекулярної діагностики Федерального наукового центру тваринництва ім. академіка Л. К. Ернста. Методи лабораторного аналізу детально наведено в роботі (Kramarenko, 2017).

Для кожного локусу МС-ДНК визначена кількість гомозиготних (Nhom) та гетерозиготних (Nhet) особин і розраховані оцінки фактичної гетерозиготності на локус $(S L H)$.

Для кожної особини визначено значення мультилокусної гетерозиготності $(M L H)$, як частка локусів МС-ДНК, що знаходилися у гетерозиготному стані від загальної кількості локусів, за якими дану особину було генотиповано.

Крім того, для кожної телиці за кожним локусом МС-ДНК розраховані абсолютна різниця між довжиною обох алелів (у кількості тандемних повторів) в індивідуальному генотипі (IDA), а також міра $d^{2}$, як квадрат різниці між довжиною обох алелів (в кількості тандемних повторів) в індивідуальному генотипі. Середню мультилокусну оцінку $d^{2}$ розраховано для всіх локусів, за якими дану особину було генотиповано, згідно методу Coulson et al. (1998).

Із фенотипових ознак для кожної телиці використані наступні (в кг): жива маса при народженні (WB), при відлученні (WW), у віці 8 міс. (W8), 12 міс. (W12), 15 міс. (W15) та 18 міс. (W18).

Оскільки жива маса телиць вірогідно відрізнялась серед особин різних підтипів (табл. 1), було використано алгоритм двофакторного дисперсійного аналізу, де у якості фіксованих факторів мінливості залежної ознаки (жива маса у різному віці) розглянуто вплив належності телиці до певного підтипу (НК або ВК), уплив генотипу за певним локусом МС-ДНК (гомо- чи гетерозиготний), а також їх сумісний вплив. Аналіз проведено окремо для кожного локусу МС-ДНК для кожної залежної ознаки.

Для перевірки гіпотези щодо відсутності зв'язку між залежною ознакою (жива маса у різному віці) та мірою $d^{2}$ було використано коефіцієнт рангової кореляції Спірмена $(R s)$. Аналіз проведено окремо для кожного підтипу, кожного локусу МCДНК та для кожної залежної ознаки.

Таблиця 1 - Показники мінливості (Mean $\pm S E)$ живої маси телиць ПМП різних підтипів в різному віці, кг

\begin{tabular}{lcc}
\hline & Ознака & \multicolumn{2}{c}{ Підтип } \\
\cline { 2 - 3 } & низькокровний $(\mathrm{HК})(n=36)$ & висококровний (BК) $(n=38)$ \\
\hline WB & $23,8 \pm 0,5$ & $21,8 \pm 0,5^{* *}$ \\
WW & $193,4 \pm 5,3$ & $168,6 \pm 5,0^{* *}$ \\
W8 & $205,1 \pm 5,6$ & $187,4 \pm 5,7^{*}$ \\
W12 & $247,7 \pm 6,9$ & $216,6 \pm 6,5^{* *}$ \\
W15 & $295,9 \pm 9,8$ & $263,8 \pm 6,9^{* *}$ \\
W18 & $351,5 \pm 12,3$ & $315,7 \pm 7,6^{*}$ \\
\hline
\end{tabular}

Примітка: ${ }^{*}-P \leq 0,05 ; * *-P \leq 0,01$. 
Для перевірки гіпотези щодо відсутності зв'язку між залежною ознакою (жива маса у різному віці) та індивідуальними оцінками мультилокусної гетерозиготності $(M L H)$ та середньої мультилокусної міри $d^{2}$ використано алгоритм дисперсійного аналізу, де у якості факторної змінної використано градації ознак. Оцінки $M L H$ було згруповано у шість класів: менше 0,50 , $0,51-0,60,0,61-0,70,0,71-0,80,0,81-0,90$ та більше 0,91 . Оцінки середньої мультилокусної міри $d^{2}$ також було згруповано у шість класів: менше 5,0, 5,1-10,0, 10,1-15,0, 15,1-20,0, 20,125,0 та більше 25,1 .

Всю статистичну обробку проведено на підставі посібника Kramarenko et al. (2019) за допомогою програмного забезпечення STATISTICA v.7 (Stat Soft Inc.).

\section{Результати}

В цілому для всіх аналізованих локусів МС-ДНК відмічалися суттєві відмінності у кількості особин, які мають гомо- та гетерозиготний генотип (критерій хі-квадрат: $\chi 2=139,54 ; d f$ $=9 ; P<0,001)$ та, відповідно, у відношенні оцінки фактичної гетерозиготності (табл. 2). Найнижчу оцінку гетерозиготності було відмічено для локусу $T G L A 53(0,421)$, а найвищу - для локусу $B M 1818(0,820)$.

Ступінь прояву гетерозиготності (тобто, квадрат різниці між довжиною алелів в індивідуальному генотипі, виражених у тандемних повторах) також суттєво варіювала для окремих локусів МС-ДНК. Найменшу оцінку цей показник мав для локусу

Таблиця 2 - Кількість гомозиготних (Nhom) та гетерозиготних (Nhet) телиць ПМП, оцінки фактичної гетерозиготності (SLH) та середнього квадрату різниці між алелями в індивідуальному генотипі (міра $d^{2}$ ) для 10 локусів МС-ДНК

\begin{tabular}{lcccc}
\hline Локус & $\begin{array}{c}\text { Кількість гомозиготних } \\
\text { особин (Nhom) }\end{array}$ & $\begin{array}{c}\text { Кількість гетерозиготних } \\
\text { особин (Nhet) }\end{array}$ & $\begin{array}{c}\text { Фактична гетерозиготність } \\
(S L H \pm S E)\end{array}$ & $\begin{array}{c}\text { Квадрат різниці між } \\
\text { довжиною обох алелів } \\
\left.\text { (міра } d^{2} \pm S E\right)\end{array}$ \\
\hline TGLA227 & 54 & 92 & $0,630 \pm 0,040$ & $20,47 \pm 2,52$ \\
BM2113 & 41 & 150 & $0,785 \pm 0,030$ & $16,34 \pm 1,40$ \\
$T G L A 53$ & 62 & 45 & $0,421 \pm 0,048$ & $5,83 \pm 1,10$ \\
$E T H 10$ & 38 & 154 & $0,802 \pm 0,029$ & $8,19 \pm 0,78$ \\
SPS115 & 54 & 138 & $0,719 \pm 0,032$ & $5,17 \pm 0,48$ \\
$T G L A 122$ & 40 & 152 & $0,792 \pm 0,029$ & $31,90 \pm 3,70$ \\
$I N R A 023$ & 47 & 145 & $0,755 \pm 0,031$ & $24,81 \pm 2,16$ \\
$B M 1818$ & 34 & 155 & $0,820 \pm 0,028$ & $6,04 \pm 0,57$ \\
$E T H 3$ & 93 & 75 & $0,446 \pm 0,038$ & $4,81 \pm 0,76$ \\
$B M 1824$ & 81 & 111 & $0,578 \pm 0,036$ & $5,36 \pm 0,79$ \\
\hline
\end{tabular}
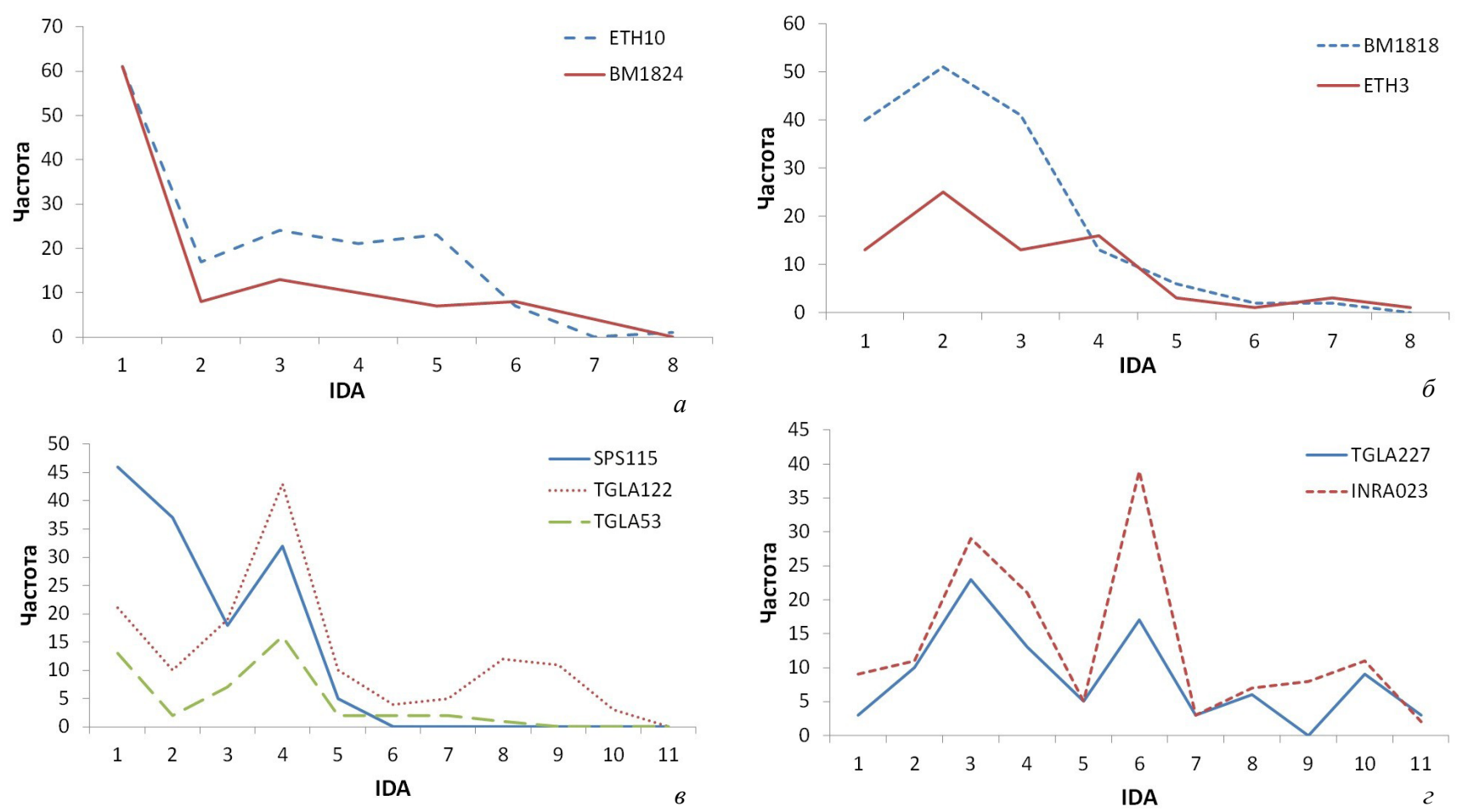

Рис. 1. Розподіл за оцінками абсолютної різниці між довжиною алелів (у тандемних повторах) в індивідуальному генотипі (IDA) телиць ПМП для різних локусів МС-ДНК: $a$-ETH10 та BM1824; 6 - BM1818 та ETH3; 6 - SPS115, TGLA122 та TGLA53; $2-$ TGLA227 та INRA023. 
Таблиця 3 - Вплив генотипу за локусами МС-ДНК на показники мінливості (Mean $\pm S E$ ) живої маси телиць ПМП в різному віці, кг

\begin{tabular}{lccc}
\hline \multirow{2}{*}{ Локус } & Ознака & \multicolumn{2}{c}{ Генотип } \\
\cline { 3 - 4 } & & гомозиготний & гетерозиготний \\
\hline$B M 2113$ & $\mathrm{~W} 15$ & $310,9 \pm 15,8(n=10)$ & $269,3 \pm 6,1^{* *}(n=49)$ \\
$B M 1818$ & $\mathrm{~W} 8$ & $171,8 \pm 12,8(n=8)$ & $198,3 \pm 4,3^{*}(n=59)$ \\
\hline
\end{tabular}

ETH3 $\left(d^{2}=4,81 \pm 0,76\right)$, а найбільшу - для локусу TGLA122 $\left(d^{2}\right.$ $=31,90 \pm 3,70)$ (див. табл. 2).

Характерно, що для вивчених локусів МС-ДНК можна виділити окремі патерни залежно від характеру розподілу за оцінками абсолютної різниці між довжиною алелів в індивідуальному генотипі (IDA) телиць ПМП. Так, для локусів ETH10 та $B M 1824$ характерно переважання гетерозиготних генотипів, що відрізняються лише одним тандемним повтором (рис. 1а). Для локусів BM1818 та ETH3 переважають гетерозиготні генотипи, що відрізняються двома тандемними повторами (рис. 1б). Для локусів SPS115, TGLA122 та TGLA53 відмічається наявність двох піків, що відповідають різниці у один та чотири тандемних повтори (рис. 1в), а для локусів TGLA227 та INRA023 - трьох піків, що відповідають трьом, шести та 10 тандемним повторам (рис. 1г).

Характерно, між оцінками фактичної гетерозиготності $(S L H)$ в розрізі окремих локусів та відповідними оцінками міри $d^{2}$ кореляція відсутня (коефіцієнт рангової кореляції Спірмена: $R s=0,503 ; P=0,138)$, що може свідчить про те, що обидва підходи відображують різні та незалежні характеристики локусів МС-ДНК.

Результати двофакторного дисперсійного аналізу підтвердили наявність вірогідного впливу фактору «підтип» на живу масу телиць ПМП в різному віці (результати не наведено). Аналіз впливу генотипу особини (гомо- чи гетерозиготний) не залежно від підтипу, до якого вона відноситься, свідчить, що лише у двох випадках була виявлена вірогідна різниця. Це стосується впливу локусу BM2113 на живу масу телиць у віці 15 міс. та впливу локусу BM1818 на живу масу телиць у віці 8 міс. (табл. 3).

При цьому, для локусу ВМ2113 гомозиготні особини вірогідно переважали особин із гетерозиготним генотипом $(310,9 \pm$ 15,8 та 269,3 $\pm 6,1$ кг у віці 15 міс., відповідно); з іншого боку, для локусу $B M 1818$, навпаки, особини із гетерозиготним гено- типом вірогідно переважали гомозигот $(198,3 \pm 4,3$ та $171,8 \pm$ 12,8 кг у віці 8 міс., відповідно).

Більш інформативними були результати аналізу сумісного впливу підтипу та генотипу за 10 локусами МС-ДНК на ознаки живої маси телиць ПМП в різному віці (табл. 4).

Лише для локусів TGLA227, BM1818 та INRA023 не було виявлено жодного випадку асоціації із живою масою телиць ПМП. Для решти локусів МС-ДНК такі випадки було зафіксовано від одного до трьох разів. В найбільшому ступені вірогідний вплив гетерозиготності за локусами МС-ДНК на їх живу масу було відмічено при народженні та у віці 15 міс. (див. табл. 4).

Вірогідний сумісний вплив, виявлений нами при аналізі, свідчить про те, що різниця між гомо- та гетерозиготними особинами відрізняється (як за величиною, так й за рівнем вірогідності) серед телиць різних підтипів (табл. 5).

Так, наприклад, асоціація між гетерозиготністю за локусом BM2113 та живою масою при народженні мала місце для особин низькровного підтипу $(25,6 \pm 0,8$ кг для гомозиготних та $23,2 \pm 0,5$ кг для гетерозиготних генотипів, відповідно). Серед особин висококровного підтипу вірогідна різниця була відсутня (див. табл. 5).

При наявності вірогідного впливу локусу мали місце як випадки переважання гомозиготних генотипів над гетерозиготними, так й переважання гетерозиготних генотипів над гомозиготними (див. табл. 5).

В табл. 6 наведено оцінки коефіцієнтів рангової кореляції Спірмена між живою масою телиць ПМП в різному віці та індивідуальними оцінками середнього квадрату різниці між алелями в індивідуальному генотипі (міра $d^{2}$ ) для 10 локусів МС-ДНК.

Для чотирьох локусів МC-ДНК (BM2113, SPS115, ETH3 та ВM1824) встановлено наявність асоціації між живою масою телиць ПМП та ступенем прояву гетерозиготності. При цьому,

Таблиця 4 - Оцінка сумісного впливу підтипу та генотипу за 10 локусами МС-ДНК на ознаки живої маси телиць ПМП в різному віці

\begin{tabular}{|c|c|c|c|c|c|c|}
\hline \multirow{2}{*}{ Локус } & \multicolumn{6}{|c|}{ Ознака } \\
\hline & WB & WW & W8 & W12 & W15 & W18 \\
\hline$T G L A 227$ & $\mathrm{~ns}$ & $\mathrm{~ns}$ & $\mathrm{~ns}$ & $\mathrm{~ns}$ & $\mathrm{~ns}$ & $\mathrm{~ns}$ \\
\hline$B M 2113$ & $*$ & ns & ns & ns & ns & ns \\
\hline TGLA53 & $*$ & $\mathrm{~ns}$ & ns & ns & $\mathrm{ns}$ & ns \\
\hline ETH10 & $\mathrm{ns}$ & $\mathrm{ns}$ & $\mathrm{ns}$ & $\mathrm{ns}$ & $\mathrm{ns}$ & $*$ \\
\hline SPS115 & $\mathrm{ns}$ & $*$ & $\mathrm{~ns}$ & $*$ & $*$ & $\mathrm{~ns}$ \\
\hline TGLA122 & $\mathrm{ns}$ & $\mathrm{ns}$ & $*$ & ns & $*$ & $\mathrm{~ns}$ \\
\hline INRA023 & $\mathrm{ns}$ & $\mathrm{ns}$ & $\mathrm{ns}$ & $\mathrm{ns}$ & $\mathrm{ns}$ & $\mathrm{ns}$ \\
\hline BM1818 & ns & ns & ns & $\mathrm{ns}$ & $\mathrm{ns}$ & ns \\
\hline ЕTH3 & ns & $\mathrm{ns}$ & $\mathrm{ns}$ & $\mathrm{ns}$ & $*$ & $*$ \\
\hline BM1824 & $*$ & ns & $\mathrm{ns}$ & ns & $*$ & $\mathrm{~ns}$ \\
\hline
\end{tabular}

Примітка: $\mathrm{ns}-P>0,05$. 
Таблиця 5 - Вплив генотипу за локусами МС-ДНК та підтипу на показники мінливості (Mean $\pm S E)$ живої маси телиць ПМП в різному віці, кг

\begin{tabular}{lccccc}
\hline \multirow{2}{*}{ Локус } & \multirow{2}{*}{ Ознака } & \multicolumn{2}{c}{ Низькокровний (НК) підтип } & \multicolumn{2}{c}{ Висококровний (ВК) підтип } \\
\cline { 3 - 6 } & & гомозиготний генотип & гетерозиготний генотип & гомозиготний генотип & гетерозиготний генотип \\
\hline BM2113 & WB & $25,6 \pm 0,8(n=9)$ & $23,2 \pm 0,5^{*}(n=27)$ & $20,0 \pm 1,7(n=3)$ & $21,9 \pm 0,5(n=35)$ \\
$S P S 115$ & WW & $204,7 \pm 14,9(n=7)$ & $190,6 \pm 5,5(n=25)$ & $151,2 \pm 8,9(n=13)$ & $177,7 \pm 6,1 * *(n=25)$ \\
$T G L A 122$ & W8 & $188,7 \pm 11,3(n=9)$ & $212,6 \pm 5,9^{*}(n=22)$ & $195,6 \pm 10,8(n=10)$ & $184,5 \pm 6,7(n=28)$ \\
\hline
\end{tabular}

Таблиця 6 - Коефіцієнти рангової кореляції Спірмена між живою масою телиць ПМП в різному віці та індивідуальними оцінками середнього квадрату різниці між алелями в індивідуальному генотипі (міра $d^{2}$ ) для 10 локусів МС-ДНК

\begin{tabular}{|c|c|c|}
\hline \multirow{2}{*}{ Локус } & \multicolumn{2}{|c|}{ Підтип } \\
\hline & Низькокровний $(n=36)$ & Висококровний $(n=38)$ \\
\hline$T G L A 227$ & ns & ns \\
\hline$B M 2113$ & WB $(-0,432 * *)$ & W15 $\left(-0,333^{*}\right)$ \\
\hline TGLA53 & ns & ns \\
\hline ETH10 & ns & ns \\
\hline SPS115 & ns & $\begin{array}{l}\text { WW }\left(0,369^{*}\right) \\
\text { W8 }\left(0,353^{*}\right) \\
\text { W12 }\left(0,374^{*}\right) \\
\text { W15 }\left(0,443^{*}\right) \\
\text { W18 }\left(0,420^{*}\right)\end{array}$ \\
\hline TGLA122 & ns & $\mathrm{ns}$ \\
\hline INRA023 & ns & ns \\
\hline$B M 1818$ & ns & ns \\
\hline ЕTH3 & $\mathrm{WW}\left(0,404^{*}\right)$ & ns \\
\hline BM1824 & $\begin{array}{l}\text { WB }(-0,353 *) \\
\text { W15 }(0,462 *)\end{array}$ & ns \\
\hline
\end{tabular}

для трьох останніх асоціацію відмічено лише для телиць одного підтипу (або низько-, або висококровного) і лише для локусу BM2113 ця асоціація мала місце у тварин обох підтипів (див. табл. 6).

Найбільш суттєвий зв'язок із індивідуальною мірою $d^{2}$ відмічено серед тварин висококровного підтипу у відношенні локусу SPS115. В цьому випадку вірогідні оцінки коефіцієнту рангової кореляції Спірмена отримано для всіх фенотипових ознак, крім живої маси при народженні (див. табл. 6).
У розрізі окремих ознак, в найбільшому ступені зв'язок між мірою $d^{2}$ відмічено для живої маси при народженні, при відлученні та у віці 15 міс. (див. табл. 6), що співпадає із результатами, отриманими раніше при аналізі впливу типу генотипу (гомо- чи гетерозиготний) (див. табл. 4).

Виявлені зв'язки у більшості випадків мали позитивний знак, тобто, чим більше відрізняються алелі за довжиною в межах індивідуального генотипу, тим вище була жива маса телиць. Особливо, це характерно для локусу SPS115, а також для
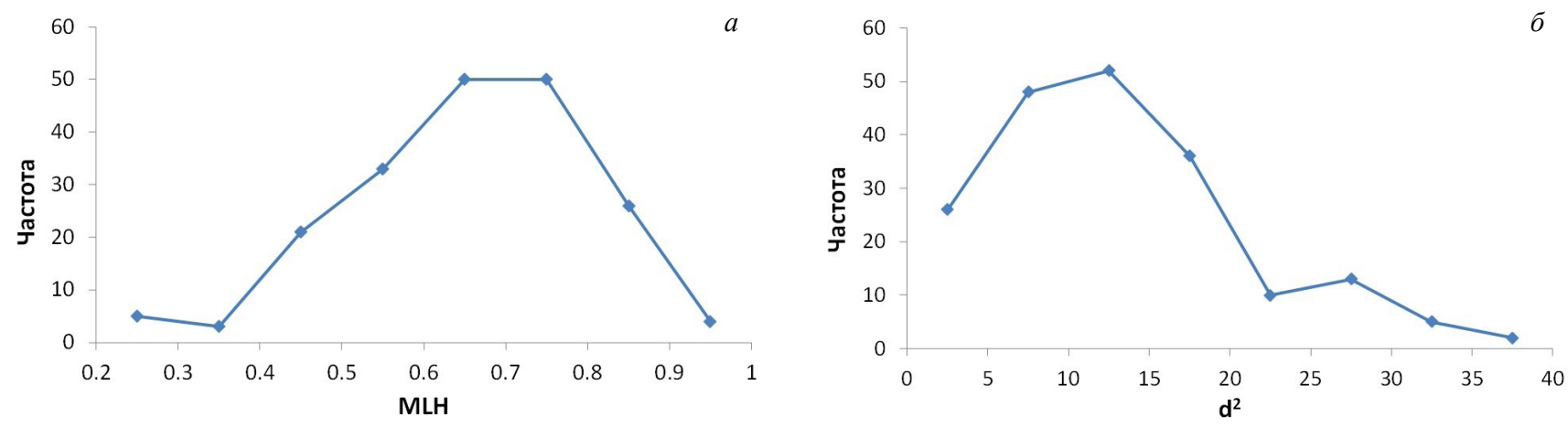

Рис. 2. Розподіл за оцінками мультилокусної гетерозиготності $(M L H)$ для телиць ПМП (a) та середнього квадрату різниці між алелями в індивідуальному генотипі (середня мультилокусна міра $d^{2}$ ) для 10 локусів МС-ДНК (б) 

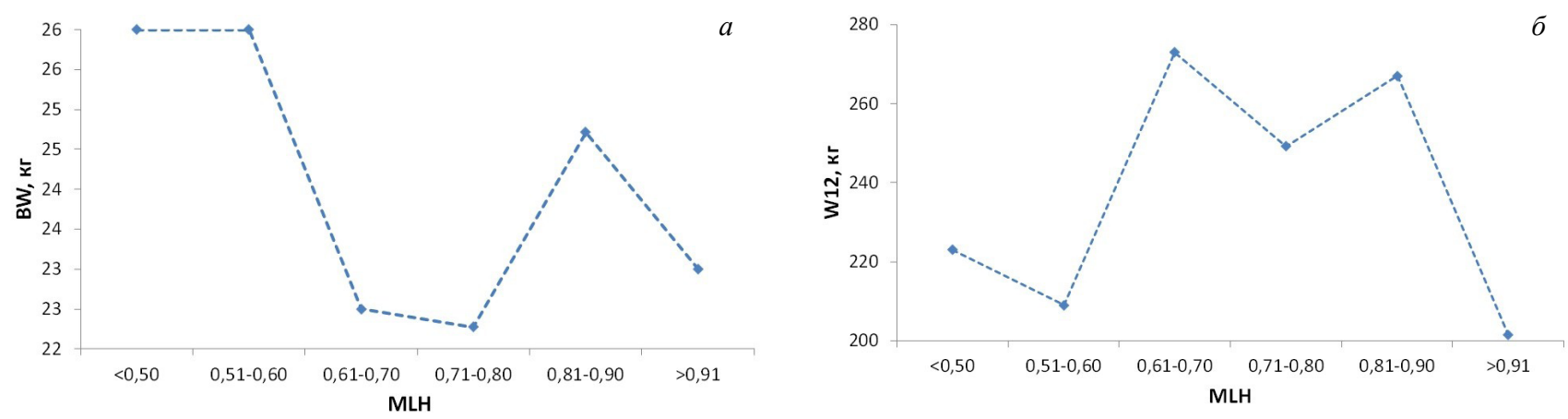

Рис. 3. Вплив середньої мультилокусної гетерозиготності $(M L H)$ для 10 локусів МС-ДНК на живу масу телиць ПМП низькокровного підтипу при народженні (a) та у віці 12 міс. (б)

локусів ETH3 та ВM1824. Негативний знак асоціації між мірою $d^{2}$ та живою масою при народженні (серед тварин низькокровного підтипу) та у віці 15 міс. (серед тварин висококровного підтипу) виявлено для локусу BM2113. Нарешті, для локусу BM1824 відмічено зміну знаку в онтогенезі з негативного (для живої маси при народженні) на позитивний (для живої маси у віці 15 міс.).

Таким чином, встановлено наявність зв'язку між двома різними формами гетерозиготності та живою масою телиць ПМП, але прояв та напрямок цього зв'язку не співпадав у розрізі окремих локусів МС-ДНК.

На рис. 2 наведено розподіл за оцінками мультилокусної гетерозиготності (MLH) для телиць ПМП та середнього квадрату різниці між алелями в індивідуальному генотипі (середня мультилокусна міра $d^{2}$ ) для 10 локусів МС-ДНК. В обох випадках розподіл мав асиметричну форму із довгим «хвостом» у бік низьких значень для $M L H$ та у бік високих значень для міри $d^{2}$.

В межах окремих особин оцінки мультилокусної гетерозиготності $(M L H)$ варіювали від 0,300 до 1,000 із середнім значенням $0,685 \pm 0,011$, а оцінки середньої мультилокусної міри $d^{2}$ варіювали від 1,57 до 39,11 із середнім значенням $13,16 \pm 0,56$ тандемних повторів ${ }^{2}$.

Встановлено наявність вірогідного та позитивного зв'язку між індивідуальними оцінками $M L H$ та середньої мультилокусної міри $d^{2}(r=0,363 ; P<0,001)$.

Вірогідний вплив градації за $M L H$ на живу масу телиць ПМП встановлено лише для живої маси тварин низькокровного підтипу при народженні $\left(F_{5} ; 30=2,57 ; P=0,047\right)$ та у віці 12

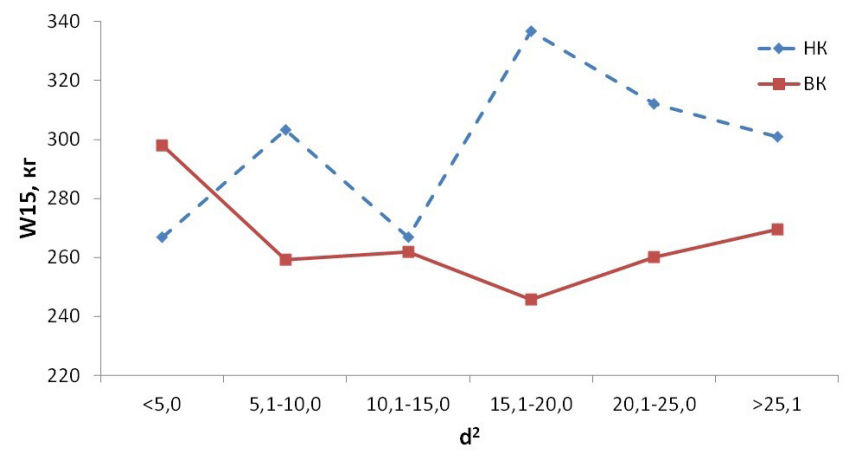

Рис. 4. Вплив підтипу та оцінок середнього квадрату різниці між алелями в індивідуальному генотипі (середня мультилокусна міра $d^{2}$ ) для 10 локусів МС-ДНК на живу масу телиць ПМП у віці 15 міс. міс. $\left(F_{5} ; 25=3,05 ; P=0,028\right)$. При цьому, характер зв'язку між індивідуальними оцінками $M L H$ та живою масою змінюється у ході онтогенезу. При народженні телиці із найнижчою живою масою характеризувалися близькими до середньої оцінками $M L H$ (рис. $3 a$ ), а у віці 12 міс., навпаки, тварини із оцінками мультилокусної гетерозиготності у межах 0,60-0,90 мали найвищу живу масу (рис. 3б).

У відношенні оцінок середнього квадрату різниці між алелями в індивідуальному генотипі (середня мультилокусна міра $d^{2}$ ) нами вірогідних зв'язків із живою масою телиць ПМП в різному віці не встановлено. Доведено, що відповідні оцінки вірогідно відрізнялися $\left(F_{5} ; 47=2,54 ; P=0,041\right)$ у тварин різних підтипів для живої маси у віці 15 міс. (рис. 4).

Так, для телиць низькокровного підтипу, які мали оцінку міри $d^{2}$ в межах 15,1-20,0 тандемних повторів ${ }^{2}$, жива маса у віці 15 міс. була найвищою, а телиці висококровного підтипу з тими же оцінками міри $d^{2}$, навпаки, мали найнижчу живу масу в цьому віці (див. рис. 4).

\section{Обговорення}

Було встановлено, що у свійських і сільськогосподарських тварин гетерозиготність вірогідно впливала на проміри тіла (Appleyard et al., 2001; Curik et al., 2003; Agatep, 2015), репродуктивні ознаки (Kashtanov et al., 2003), якість м'яса (Liu et al., 2003), вміст жиру в молоці (Jiang et al., 2004), стійкість до паразитів (Luikart et al., 2008) та хвороб (Driscoll et al., 2011; Smith et a., 2012; Valilou et al., 2016). Але найчастіше було встановлено наявність певної асоціації між показниками гетерозиготності із живою масою та їх приростами (Wu et al., 2001; Zhang et al., 2005; Liu et al., 2006; Han et al., 2013; Iversen et al., 2019), що відмічено й у нашому дослідженні. Так, для телиць ПМП нами доведено вірогідний вплив локусу $B M 2113$ на живу масу у віці 15 міс. та локусу BM1818 на живу масу у віці 8 міс. (див. табл. 3). В розрізі різних підтипів для більшості локусів МСДНК зв'язок між локусами МС-ДНК відмічено для живої маси при народженні та у віці 15 міс. (див. табл. 4). Характерно, що раніше (Kramarenko et al., 2020) нами встановлено три алеля $\left(B M 1824^{178}, T G L A 227^{83}, B M 1818^{258}\right)$, наявність яких у генотипі телиць ПМП забезпечувала більш інтенсивний ріст живої маси та один алель $\left(B M 2113^{141}\right)$, що пов'язаний із повільним зростанням живої маси у різні вікові періоди.

Наявність вірогідних зв'язків між ознаками та гетерозиготністю за окремими локусами МС-ДНК раніше вже доведено для різних тварин. Так, гетерозиготність за локусом UNH146 впливала на довжину тіла та живу масу прісноводної тилапії (Oreochromis spp.), гетерозиготність за локусами INRA111 та BMS2847 пов'язана із стійкістю свійської худоби до туберкульозу (Driscoll et al., 2011), а гетерозиготність за локусом 
BMC5221 - із стійкістю до копитної гнилі у овець (Smith et a., 2012; Valilou et al., 2016).

При цьому, як і в нашому випадку, цей зв'язок не завжди демонструє перевагу особин із гетерозиготним генотипом над гомозиготами, що можна було б очікувати, виходячи з теорії гетерозису. Перевагу гомозиготних особин над гетерозиготами було відмічено, наприклад, для довжини тіла тилапії (Appleyard et al., 2001). 3 іншого боку, вівці гомозиготні за локусом ВMC5221 характеризувалися підвищеним ризиком захворіти на копитну гниль, а в групі тварин, де цю хворобу не було виявлено, навпаки, спостерігався дуже значний дефіцит гомозигот за цим локусом (Smith et a., 2012; Valilou et al., 2016).

Аналогічна ситуація мала місце і у відношенні зв'язку індивідуальних оцінок мультилокусної гетерозиготності $(M L H)$ iз ознаками продуктивності. Встановлено (Wu et al., 2001), що для свиней оцінки $M L H$, що були отримані для 56 локусів MCДНК, розташованих на 1-й, 2-й, 11-й, 13-й, 17-й та 18-й хромосомах (т.зв. геномна гетерозиготність, genomic heterozygosity), вірогідно та позитивно пов'язані із забійною масою та середньодобовими приростами живої маси тварин, хоча при цьому зв'язок із товщиною шпику був відсутній. Оцінки $M L H$, розраховані для 15 локусів МС-ДНК, були вірогідно та негативно пов'язані із кількістю легеневих гельмінтів (Protostrongylus spp.) у диких баранів-товсторогів (Luikart et al., 2008). Також були відмічені вірогідні асоціації між індивідуальними оцінками мультилокусної гетерозиготності та живою масою, висотою у холці, довжиною тіла, обхватом грудей та обхватом п'ястка у кіз породи Tongshan Black-boned (Han et al., 2013).

У цілому, зв'язок геномної гетерозиготності із ознаками варіює від хромосоми до хромосоми, а асоціація між гетерозиготністю та продуктивністю носить скоріше нелінійний комплексний характер внаслідок складної взаємодій між окремими генами (Wu et al., 2001).

Вірогідний зв'язок також мав місце між середньою мультилокусною оцінкою міри $d^{2}$ та певними промірами тіла кобил породи Lipizzan (Curik et al., 2003). 3 іншого боку, вірогідної кореляції між оцінками міри $d^{2}$ та живою масою курей відмічено не було (Liu et al., 2006), як й в нашому дослідженні.

Існують також підтвердження гіпотези про те, що посилення паразитизму та чутливість до хвороб може бути наслідком зниженої гетерозиготності у популяціях диких і свійських тварин, а деякі окремі локуси можуть обумовлювати стійкість до паразитів та хвороб (Luikart et al., 2008; Driscoll et al., 2011; Smith et a., 2012). Також, індивідуальний рівень гетерозиготності може бути використано у якості прогностичної ознаки при аналізі ростових процесів сільськогосподарських тварин (Han et al., 2013). Важливою перевагою цього підходу є те, що він може бути використаний вже на ранніх етапах онтогенезу (Agatep, 2015).

Таким чином, використання моделей, що включають оцінки гетерозиготності, призводить до більш точного відбору ремонтних тварин для селекційних цілей, що може збільшити генетичний приріст ознак продуктивності, ймовірно, внаслідок домінантної дії окремих генів (Iversen et al., 2019).

\section{Висновки}

Аналіз впливу генотипу телиць ПМП (гомо- чи гетерозиготний) не залежно від підтипу, до якого вона відноситься, свідчить, що лише у двох випадках було виявлено вірогідну різницю. Це стосується впливу локусу $B M 2113$ на живу масу телиць у віці 15 міс. та впливу локусу $B M 1818$ на живу масу телиць у віці 8 міс. Для чотирьох локусів МС-ДНК (BM2113, $S P S 115$, ETH3 та BM1824) встановлено наявність асоціації між живою масою телиць ПМП та ступенем прояву гетерозиготності. Найбільш суттєвий зв'язок із індивідуальною мірою $d^{2}$ було відмічено серед тварин висококровного підтипу у відношенні локусу SPS115. У розрізі окремих ознак, у найбільшому ступені зв'язок між мірою $d^{2}$ відмічено для живої маси при народженні, при відлученні та у віці 15 міс. В цілому, оцінки індивідуальної гетерозиготності для 10 локусів МС-ДНК та середні мультилокусні оцінки $d^{2}$ були слабко пов'язані із живою масою телиць південної м'ясної породи.

\section{Подяки}

Робота виконана в рамках фінансування за держбюджетною тематикою Міністерства освіти і науки України (номер державної реєстрації - 0121U109492).

\section{References}

Agatep, R. C. (2015). Microsatellite loci heterozygosity and fitness correlations among three genetic groups of domesticated mallard ducks (Anas platyrhynchos domesticus L.) in the Philippines. Journal of Agricultural Technology, 11(7), 1439-1447.

Appleyard, S. A., Renwick, J. M., \& Mather, P. B. (2001). Individual heterozygosity levels and relative growth performance inOreochromis niloticus(L.) cultured under Fijian conditions. Aquaculture Research, 32(4), 287-296.

Coulson, T. N., Pemberton, J. M., Albon, S. D., Beaumont, M., Marshall, T. C., Guinness, F. E., \& Clutton-Brock, T. H. (1998). Microsatellites reveal heterosis in red deer. Proceedings of the Royal Society of London. Series B: Biological Sciences, 265(1395), 489-495.

Curik, I., Zechner, P., Sölkner, J., Achmann, R., Bodo, I., Dovc, P., Kavar, T., Marti, E., \& Brem, G. (2003). Inbreeding, microsatellite heterozygosity, and morphological traits in Lipizzan horses. Journal of Heredity, 94(2), 125-132.

Driscoll, E. E., Hoffman, J. I., Green, L. E., Medley, G. F., \& Amos, W. (2011). A preliminary study of genetic factors that influence susceptibility to bovine tuberculosis in the British cattle herd. PLoS One, 6(4), e18806.

Han, Y. G., Liu, G. Q., Jiang, X. P., Liang, G. M., He, C. B., Wang, D. W., Wu, Y., Xiang, X. L., Hu, J. \& Peng, Y. Q. (2013). Investigation of individual heterozygosity correlated to growth traits in Tongshan Black-boned goat. Molecular Biology Reports, 40(11), 6075-6079.

Iversen, M. W., Nordbø, Ø., Gjerlaug-Enger, E., Grindflek, E., Lopes, M. S., \& Meuwissen, T. (2019). Effects of heterozygosity on performance of purebred and crossbred pigs. Genetics Selection Evolution, 51(1), 1-13.

Jiang, X. P., Liu, G. Q., Wang, C., Mao, Y. J., \& Xiong, Y. Z. (2004). Milk trait heritability and correlation with heterozygosity in yak. Journal of Applied Genetics, 45(2), 215-224. PMID: 15131352

Jiang, X. P., Liu, G. Q., \& Xiong, Y. Z. (2005). Investigation of gene and microsatellite heterozygosities correlated to growth rate in the Chinese Meishan pig. Asian-Australasian Journal of Animal Sciences, 18(7), 927-932

Kashtanov, S. N., Lazebny, O. E., \& Gracheva, S. V. (2003). Fitness characteristics and allozyme heterozygosity in an artificial population of the sable Martes zibellina L. Russian Journal of Genetics, 39(12), 1438-1441

Kramarenko, A. S., Sukhoruchko, T. O., \& Kramarenko, S. S. (2020). Polimorfizm ta asotsiatsiia STR-lokusiv iz oznakamy rostu telyts pivdennoi miasnoi porody [Polymorphism and association of STR loci with growth traits in heifers of the Southern beef cattle]. Taurida Scientific Herald. Series: Rural Sciences, 113, 181-192 (in Ukrainian).

Kramarenko, O. S. (2017). Otsiniuvannia henetychnoi struktury ta prohnozuvannia produktyvnosti tvaryn pivdennoi m'yasnoi porody za DNK-markeramy [Estimation of genetic structure and prediction of productivity in animals of Southern Meat breed based on DNA markers]. Ilion, Mykolayiv (in Ukrainian). 
Kramarenko, S. S., Lugovy, S. I., Lykhach, A. V. \& Kramarenko, O. S. (2019). Analiz biometrychnykh danykh u rozvedenni ta selektsiyi tvaryn [Analysis of biometric data in animal breeding and selection]. MNAU, Mykolayiv (in Ukrainian).

Liu, G. Q., Jiang, X. P., Xiong, Y., Deng, C., \& Qu, Y. (2003). Effects of individual gene heterozygosity on meat quality traits in swine. Journal of Nanjing Agricultural University, 26(1), 56-60 (in Chinese).

Liu, G. Q., Jiang, X. P., Wang, J. Y., \& Wang, Z. Y. (2006). Correlations between heterozygosity at microsatellite loci, mean $\mathrm{d} 2$ and body weight in a Chinese native chicken. Asian-Australasian Journal of Animal Sciences, 19(12), 1671-1677.

Luikart, G., Pilgrim, K., Visty, J., Ezenwa, V. O., \& Schwartz, M. K. (2008). Candidate gene microsatellite variation is associated with parasitism in wild bighorn sheep. Biology Letters, 4(2), 228-231.

Luís, C., Cothran, E. G., \& Oom, M. D. M. (2007). Inbreeding and genetic structure in the endangered Sorraia horse breed: implications for its conservation and management. Journal of Heredity, 98(3), 232-237.

Singh, S. M., \& Zouros, E. (1978). Genetic variation associated with growth rate in the American oyster (Crassostrea virginica). Evolution, 32(2), 342-353.
Smith, E. M., Hoffman, J. I., Green, L. E., \& Amos, W. (2012). Preliminary association of microsatellite heterozygosity with footrot in domestic sheep. Livestock Science, 143(2-3), 293-299.

Valilou, R. H., Sarskanroud, M. R., Rafat, S. A., Ebrahimi, M., Firouzamandi, M., \& Mohammadi, S. A. (2016). Association between footrot resistance and microsatellite polymorphisms of ovar-DRB1 and BMC5221 loci in Iranian Ghezel sheep. Revue de Medecine Veterinaire, 167(11-12), 316-322.

Wu, X. L., Li, X., \& Merete, F. (2001). Association of microsatellite genomic heterozygosity with inbred pig performance under successive inbreeding. Acta Genetica Sinica, 28(1), 20-28 (in Chinese). PMID: 11209707

Zhang, J. H., Xiong, Y. Z., \& Deng, C. Y. (2005). Correlations of genic heterozygosity and variances with heterosis in a pig population revealed by microsatellite DNA marker. Asian-Australasian Journal of Animal Sciences, 18(5), 620-625.

Zouros, E. (1993). Associative overdominance: evaluating the effects of inbreeding and linkage disequilibrium. Genetica, 89(1), 35-46. 